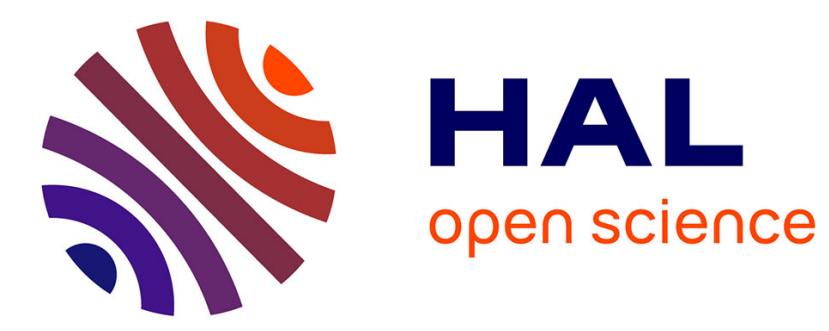

\title{
Total synthesis of cyclotheonamide C using a tandem backbone-extension-coupling methodology
}

\author{
Stéphane Roche, Sophie Roy-Faure, D.J. Aitken
}

\section{To cite this version:}

Stéphane Roche, Sophie Roy-Faure, D.J. Aitken. Total synthesis of cyclotheonamide C using a tandem backbone-extension-coupling methodology. Angewandte Chemie International Edition, 2008, 47, pp.6840-6842. hal-00323870

\section{HAL Id: hal-00323870 \\ https://hal.science/hal-00323870}

Submitted on 23 Sep 2008

HAL is a multi-disciplinary open access archive for the deposit and dissemination of scientific research documents, whether they are published or not. The documents may come from teaching and research institutions in France or abroad, or from public or private research centers.
L'archive ouverte pluridisciplinaire HAL, est destinée au dépôt et à la diffusion de documents scientifiques de niveau recherche, publiés ou non, émanant des établissements d'enseignement et de recherche français ou étrangers, des laboratoires publics ou privés. 


\title{
Total Synthesis of Cyclotheonamide $\mathrm{C}$ using a Tandem Backbone- Extension-Coupling Methodology $* *$
}

\author{
Stéphane P. Roche, Sophie Faure, and David J. Aitken*
}

The cyclotheonamides $(\mathrm{Ct})$ are a family of nine macrocyclic pentapeptides isolated from the sponges Theonella swinhoei and ircinia. ${ }^{[1]}$ A common structural feature of these compounds is a highly electrophilic $\alpha$-keto- $\beta$-arginine (k-Arg) moiety, which is responsible for their potency as inhibitors of serine proteases of the trypsin family, ${ }^{[1,2,3 b]}$ including thrombin, for which $\mathrm{IC}_{50}$ values are in the $3-80 \mathrm{~nm}$ range. ${ }^{[1]}$ The challenge of the total synthesis of these compounds has inspired several groups, leading to successful preparations of the first two members of the family, CtA and $\mathrm{CtB} \cdot{ }^{[3]}$ In each of these syntheses, the k-Arg moiety was prepared using a multistep sequence as a discrete, protected amino acid building block in the first instance, then introduced conventionally into the peptide chain assembly. The reactive carbonyl function was masked as a protected secondary alcohol, being unveiled by deprotection and oxidation in the last stages of the synthesis A more recent report on the total synthesis of CtE2 and CtE3 constitutes an alternative approach to the construction of the $\mathrm{k}$-Arg-containing fragment, since an $\alpha$-Argderived component was homologated to $\mathrm{k}$-Arg at the same time as the next amino acid residue was coupled. ${ }^{[4]}$ An inconvenience in this approach is arguably the premature appearance of the free k-Arg carbonyl function. Nevertheless, the attractive, tandem one-pot homologation-coupling approach seemed to us an expedient strategy for the synthesis of cyclotheonamides. We sought a procedure which could combine the rapidity of construction with the provision of a protecting feature, allowing creation of a masked k-Arg within a peptide sequence. Herein, we describe such an

[^] Prof. Dr. D. J. Aitken

Université Paris-Sud 11, Laboratoire de Synthèse Organique \& Méthodologie

Institut de Chimie Moléculaire et des Matériaux d'Orsay (CNRS UMR 8182)

15 rue Georges Clemenceau, 91405 Orsay cedex (France)

Fax: $(+33)$ 1-6915-6278

E-mail: david.aitken@u-psud.fr

Dr. S. P. Roche, Dr. S. Faure

Université Blaise Pascal-Clermont-Ferrand 2

Laboratoire de Synthèse et Etudes de Systèmes à Intérêt Biologique (CNRS UMR 6504)

24 avenue des Landais, 63177 Aubière cedex (France)

[^*] We thank B. Légeret for mass spectral analyses and the Ministère de la Recherche for a PhD grant to S.P.R. approach for the first total synthesis of $\mathrm{CtC}^{[1 \mathrm{~b}]}$ a unique member of the $\mathrm{Ct}$ family in that it possesses a fully conjugated vinylogous dehydrotyrosine (V- $\Delta \mathrm{Tyr}$ ) structural feature, which adds to the synthetic challenge of this compound.

Our synthetic plan is outlined in Figure 1. Macrocyclisation and deprotection constitute the final stages of an approach which targets a key advanced linear pentapeptide.

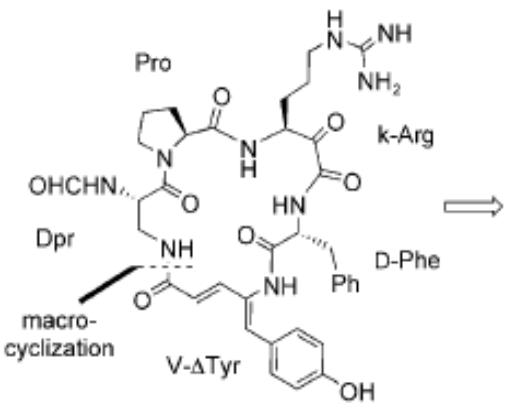

Cyclotheonamide $\mathrm{C} \quad 1$

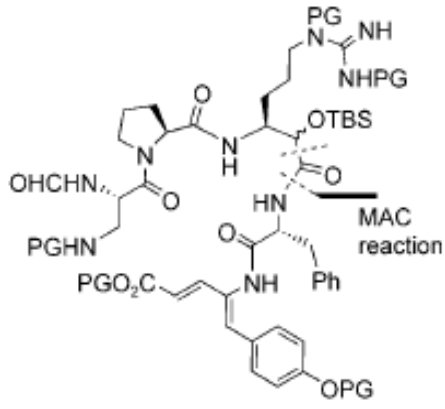

Advanced linear pentapeptide

Figure 1. Retrosynthetic analysis on cyclotheonamide $C$, identifying the key linear pentapeptide advanced intermediate structure. PG= protecting group

This intermediate features an $\alpha$-silyloxyhomoarginine serving as a masked k-Arg, which we envisaged creating using Nemoto and co-workers' masked acyl cyanide (MAC) reaction. ${ }^{[5]}$ This mild, three-component procedure combines an aldehyde, an amine and $\alpha$-(tert-butyldimethylsilyloxy)malononitrile 2 to afford an $\alpha$-silyloxycarboxamide under mild basic conditions. This reaction should allow the creation of an $\alpha$-hydroxy- $\beta$-amino carboxamide system, ${ }^{[6]}$ the central feature in our linear peptide target, from readily available $\alpha$-aminoacid-derived reactants (Scheme 1). Reputedly, the procedure is not completely diastereoselective at the newly-formed
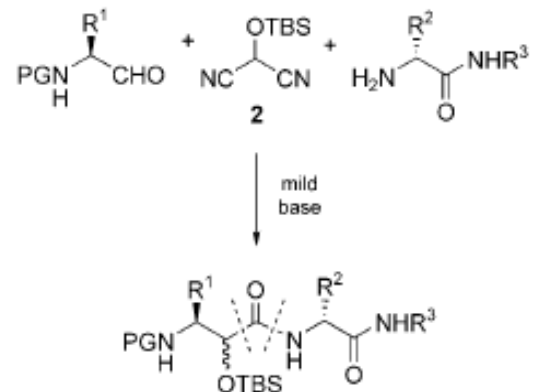

Scheme 1. The MAC reaction as a tandem backbone-extension-coupling procedure for the creation of a masked $\alpha$-keto- $\beta$-amino acid within a peptide chain. 
stereogenic centre, but this is irrelevent for our purposes, as this carbon centre is destined to become a ketone. ${ }^{[6]}$ An additional desirable feature of the MAC approach is that the mild reaction conditions should allow use of an $\alpha$-argininal derived reactant with minimal risk of epimerisation. ${ }^{[7,8]}$ The pivotal part of our synthesis was therefore the one-pot combination of a dipeptide amine for the southern part and an argininal derivative for the northern part, to create the kArg feature within a complex peptide structure.

Two aldehyde components were synthesised from a stock of the readily available Weinreb amide 3 (Scheme 2). Argininal derivative $\mathbf{4}$ was obtained by installation of the<smiles>[R]NC(=N)NCCCC(NC(=O)OCc1ccccc1)C(=O)N(C)OC</smiles>

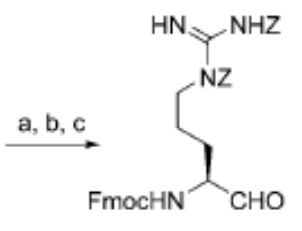
3<smiles>[R4]NC(=N)NCCC[C@H](C=O)NC(=O)[C@@H]1CCCN1C(=O)[C@H](CNC(=O)OCc1ccccc1)NC=O</smiles><smiles>O=CNC(CNC(=O)OCc1ccccc1)C(=O)N1CCC[C@H]1C(=O)O</smiles>

Scheme 2. Preparation of the aldehyde components 4 and 6 . Reagents and conditions: a) $\mathrm{TFA} / \mathrm{CH}_{2} \mathrm{Cl}_{2} 1: 1,0^{\circ} \mathrm{C}, 1 \mathrm{~h}$; b) FmocCl, $\mathrm{Na}_{2} \mathrm{CO}_{3}$, $\mathrm{H}_{2} \mathrm{O} /$ dioxane, $0^{\circ} \mathrm{C}$ to RT, $12 \mathrm{~h}, 97 \%$ (2 steps); c) $\mathrm{LiAlH}_{4}, \mathrm{THF},-30^{\circ} \mathrm{C}$, $1.5 \mathrm{~h}, 59 \%$; d) EDCI, DMAP, $5, \mathrm{CH}_{2} \mathrm{Cl}_{2}, 0^{\circ} \mathrm{C}$ to RT, $18 \mathrm{~h}$; e) $\mathrm{LiAlH}_{4}$, THF, $-10^{\circ} \mathrm{C}, 1 \mathrm{~h}, 48 \%$ (2 steps). Boc $=$ tent-butyloxycarbonyl, TFA $=$ trifluoroacetic acid, Fmoc $=9-$ fluorenylmethyloxycarbonyl, EDCI $=1-(3-$ dimethylaminopropyl)-3-ethyl carbodiimide hydrochloride, DMAP $=4$ dimethylaminopyridine.

base-labile Fmoc protecting group on $\mathrm{N}^{\alpha}$ followed by chemoselective reduction of the amide using $\mathrm{LiAlH}_{4}$ at low temperature. The tripeptide aldehyde 6 was obtained by deprotection of 3 followed by EDCI/HOBt coupling with dipeptide 5 , then selective reduction using $\mathrm{LiAlH}_{4}$. Aldehydes 4 and 6 prepared in this manner were enantiomerically pure and required minimal workup before being engaged in subsequent reactions

The requisite amine component, dipeptide $\mathbf{1 0}$, was constructed stereoselectively as follows (Scheme 3). Z-Dehydrotyrosine dipeptide 7 , obtained by adaptation of an established procedure, ${ }^{[9]}$ was reduced to give alcohol $\mathbf{8}$ in $79 \%$ yield, then Taylor and co-workers' one pot oxidationvinylogation procedure ${ }^{[10]}$ using activated manganese(IV) oxide and tert-butyloxycarbonylmethylene triphenylphosphorane gave 9 , which bears the vinylogous dehydrotyrosine feature (V- $\Delta \mathrm{Tyr}$ ) with the $E$ configuration exclusively for the new double bond. This procedure conveniently avoids the
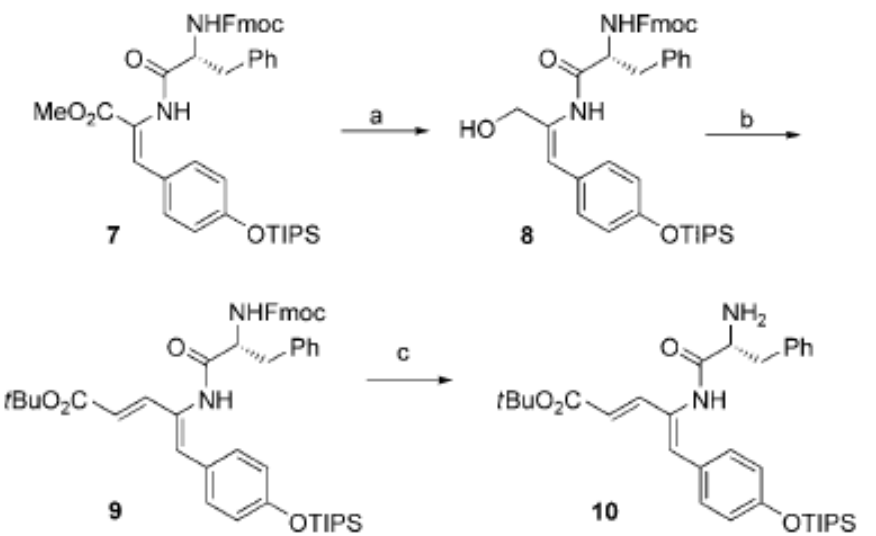

Scheme 3. Preparation of the amine component 10. Reagents and conditions: a) $\mathrm{LiAlH}_{4}, \mathrm{THF}, 0^{\circ} \mathrm{C}, 1 \mathrm{~h}, 79 \%$; b) $\mathrm{Ph}_{3} \mathrm{P}=\mathrm{CHCO}_{2} \mathrm{tBu}$, activated $\mathrm{MnO}_{2}, \mathrm{CH}_{2} \mathrm{Cl}_{2}, 40^{\circ} \mathrm{C}, 36 \mathrm{~h}, 58 \%$; c) $\mathrm{Et}_{2} \mathrm{NH} / \mathrm{CH}_{3} \mathrm{CN} 1: 2,0^{\circ} \mathrm{C}$ to RT, $1 \mathrm{~h}, 89 \%$.

need to isolate the intermediate aldehyde, which underwent degradation upon any isolation attempts. Conversion of 9 into the free amine 10 was achieved simply through treatment with diethylamine.

With the aldehyde and amine components in hand, we turned our attention to the key MAC reactions for peptide construction (Scheme 4). Targeting tripeptide 11 in the first combination, we examined various reaction conditions for the three-component reaction between argininal derivative $\mathbf{4}$, amine 10 and reagent 2 . Satisfying results (53\% yield) were obtained for a chilled two-day reaction in the presence of 4 pyrrolidinopyridine as base. $\mathrm{N}$-Terminal deprotection of $\mathbf{1 1}$ and coupling with dipeptide $\mathbf{5}$ provided the key linear pentapeptide 12. In a more spectacular fashion, tripeptide aldehyde 6 , amine $\mathbf{1 0}$ and reagent $\mathbf{2}$ were combined using MAC reaction conditions to afford the linear pentapeptide $\mathbf{1 2}$ in a single reaction, with an acceptable $24 \%$ yield. This highly convergent operation allowed the successful creation of the masked $\mathrm{k}$-Arg feature within a complex linear pentapeptide and represents the most elaborate use of such methodology to date.

Simultaneous deprotection of $\mathrm{N}$-and C-termini of pentapeptide 12 was achieved using trifluoroacetic acid, to furnish the free pentapeptide for the macrocyclisation step. Activation of the fully conjugated "push-pull" $\mathrm{V}$ - $\Delta \mathrm{Tyr} C$-terminus proved a challenge, but after some experimentation, the uronium coupling reagent TBTU, together with a stoichiometric amount of $\mathrm{HOBt}$ in a $\mathrm{DMF} / \mathrm{CH}_{2} \mathrm{Cl}_{2}$ mixture, provided the target macrocyclic peptide 13 in $69 \%$ yield. With the end of our synthesis now in sight, it was time to liberate the k-Arg moiety. Frustratingly, the action of TBAF on 13 effected complete deprotection of both alcohol and phenol functions, in further testimony to the "push-pull" effect of the extended conjugated system. Subsequent oxidation attempts on samples with an unprotected phenol led to extensive degradation of material. To our gratification, selective deprotection of the secondary alcohol TBS ether of $\mathbf{1 3}$ in the presence of the phenyl TIPS ether was achieved by the action of $1 \%$ aqueous $\mathrm{HCl}$ in ethanol at $30^{\circ} \mathrm{C} .^{[11]}$ Dess-Martin periodinane oxida- 


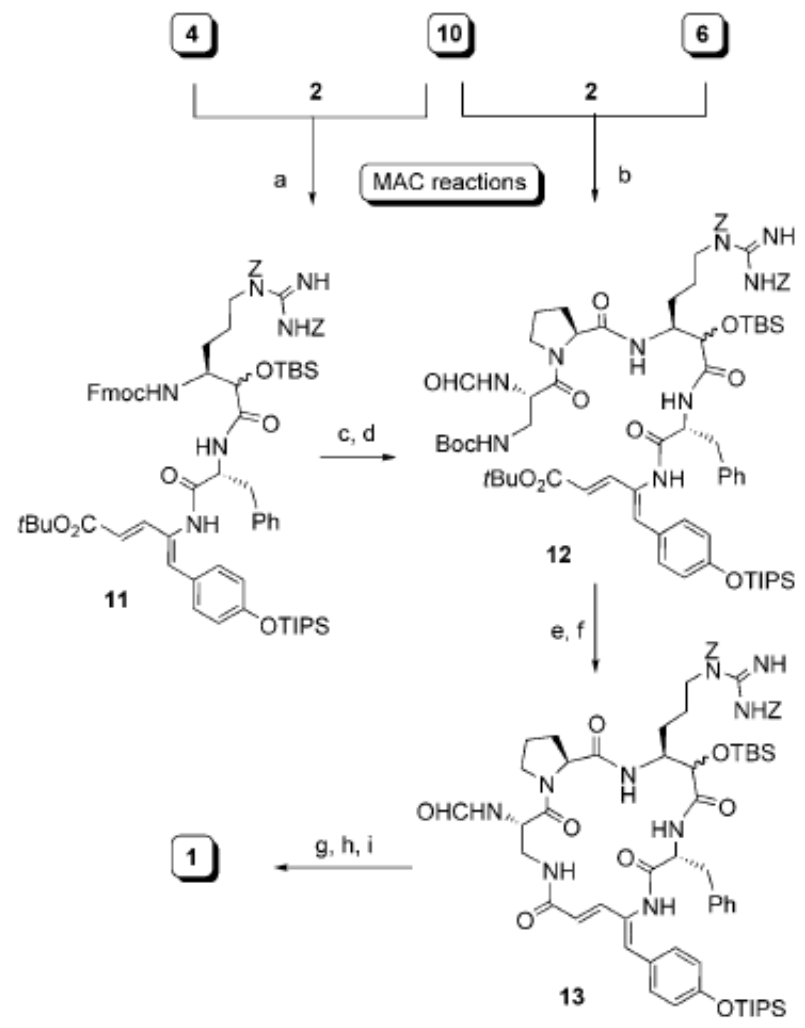

Scheme 4 Multicomponent assembly of advanced peptides leading to CtC. Reagents and conditions: a) $2,4-\mathrm{PP}$, THF, $-25^{\circ} \mathrm{C}(24 \mathrm{~h})$ then $0{ }^{\circ} \mathrm{C}$ (24 h), $53 \%$; b) 2, 4-PP, $\mathrm{CH}_{3} \mathrm{CN}, 0^{\circ} \mathrm{C}, 15 \mathrm{~h}, 24 \%$; c) $\mathrm{Et}_{2} \mathrm{NH} / \mathrm{CH}_{3} \mathrm{CN}$ $1: 2,0^{\circ} \mathrm{C}$ to RT, $1 \mathrm{~h}$; d) $5, \mathrm{EDCl}, \mathrm{HOBt}, \mathrm{CH}_{2} \mathrm{Cl}_{2}, 0^{\circ} \mathrm{C}$ to RT, $18 \mathrm{~h}, 79 \%$ (2 steps); e) TFA $/ \mathrm{CH}_{2} \mathrm{Cl}_{2} 1: 1,0^{\circ} \mathrm{C}, 1.5 \mathrm{~h}$; f) TBTU, $\mathrm{HOBt}, \mathrm{CH}_{2} \mathrm{Cl}_{2} / \mathrm{DMF}$ 2:1, $0.005 \mathrm{~m}, 0^{\circ} \mathrm{C}$ to RT, $40 \mathrm{~h}, 69 \%$ (2 steps); g) $\mathrm{HCl} / \mathrm{EtOH}, 30^{\circ} \mathrm{C}, 2 \mathrm{~h}$, $35 \%$; h) DMP, $\mathrm{CH}_{3} \mathrm{CN}, 60^{\circ} \mathrm{C}, 1 \mathrm{~h}, 71 \%$; i) HF.pyridine, anisole, RT, $12 \mathrm{~h}, 51 \%$. TBTU $=O$-(benzotriazol-1-yl)- $N, N, N^{\prime}, N^{\prime}$-tetramethyluronium tetrafluoroborate, $\mathrm{DMP}=$ Dess-Martin periodinane, 4-PP $=4-\mathrm{pyr}$ rolidinopyridine, $\mathrm{HOBt}=1$-hydroxybenzotriazole.

tion was performed smoothly to provide a derivative of CtC which was protected only on the dehydrotyrosine and arginine side chains Final deprotection of these moieties was achieved in $51 \%$ yield using pyridine hydrofluoride in the presence of anisole to furnish $\mathrm{CtC}$. $^{[12]}$

In conclusion, we have successfully achieved the first total synthesis of $\mathrm{CtC}$, using an unconventional approach for the assembly of the advanced linear pentapeptide. This multicomponent construction is epimerisation-free and obviates the need for the upstream elaboration of a k-Arg building block, and thus shortens the overall sequence compared to previous syntheses of $\mathrm{CtA}$ and $\mathrm{CtB}$.

Received: April 29, 2008

Published online: July 25, 2008

Keywords: macrocycles - multicomponent reactions . natural products - peptides - total synthesis

[1] a) N. Fusetani, S. Matsunaga, J. Am. Chem. Soc. 1990, 112,70537054 ; b) Y. Nakao, S. Matsunaga, N. Fusetani, Bioorg. Med. Chem. 1995, 3,1115-1122; c) Y. Nakao, N. Oku, S. Matsunaga, N. Fusetani, J. Nat. Prod. 1998, 61, 667-670; d) Y. Murakami, M. Takei, K. Shindo, C. Kitazume, J. Tanaka, T. Higa, H. Fukamachi, J. Nat. Prod. 2002, 65, 259-261.

[2] V. Ganesh, A. Y. Lee, J. Clardy, A. Tulinsky, Protein Sci. 1996, 5, $825-835$.

[3] a) M. Hagihara, S. L. Schreiber, J. Am. Chem. Soc. 1992, 114, 6570-6571; b) B. E. Maryanoff, X. Oiu, K. P. Padmanabhan, A. Tulinsky, H. R. Almond, P. Andrade-Gordon, M. N. Greco, J. A. Kauffman, K. C. Nicolaou, A. Liu, P. H. Brungs, N. Fusetani, Proc. Natl. Acad. Sci. USA 1993, 90,8048-8052; c) P. Wipf, H. Kim, J. Org. Chem. 1993, 58, 5592-5594; d) J. Deng, Y. Hamada, T. Shioiri, S. Matsunaga, N. Fusetani, Angew. Chem. 1994, 106, 1811-1813; Angew. Chem. Int. Ed. Engl. 1994, 33, 1729-1731; e) B. E. Maryanoff, M. N. Greco, H.-C. Zhang, P. AndradeGordon, J. A. Kauffman, K. C. Nicolaou, A. Liu, P. H. Brungs, J. Am. Chem. Sac. 1995, 117, 1225-1239; f) H. M. Bastiaans, J. L. van der Baan, C. J. Ottenheijm, Tetrahedron Lett. 1995, 36 , 5963-5966; g) J. Deng, Y. Hamada, T. Shioiri, Tetrahedron Lett. 1996, 37, 2261-2264; h) H. M. Bastiaans, J. L. van der Baan, C. J. Ottenheijm, J. Org. Chem. 1997, 62, 3880-3889.

[4] a) H. H. Wasserman, R. Zhang, Tetrahedron Lett. 2002, 43, 3743-3746; b) H. H. Wasserman, R. Zhang, Tetrahedron 2002, $58,6277-6283$.

[5] H. Nemoto, Y. Kubota, Y. Yamamoto, J. Org. Chem. 1990, 55, $4515-4516$.

[6] H. Nemoto, R. Ma, I. Suzuki, M. Shibuya, Org. Lett. 2000, 2, $4245-4247$.

[7] In the syntheses of CtA and CtB (ref. [3]), the masked k-Arg building blocks are usually elaborated with argininal derivatives which do not always benefit from mild reaction conditions and are therefore vulnerable towards epimenisation.

[8] This expectation was confirmed experimentally. A model reaction combining argininal derivative 3 , reagent 2 , and $D$ Phe-OMe was shown to proceed without epimerization. See Supporting Information for details.

[9] D. J. Aitken, S. Faure, S. Roche, Tetrahedron Lett. 2003, 44, $8827-8830$.

[10] X. Wei, R. J. K. Taylor, J. Org. Chem. 2000, 65, 616-620.

[11] R. F. Cunico, L. Bedell, J. Org. Chem. 1980, 45, 4798-4801.

[12] NMR and MS data were consistent with those obtained for the natural product. Copies of the spectra were kindly made available to us by Prof. N. Fusetani. 